\title{
THE EFFECTS OF ETHANOL EXTRACTS OF Centella asiatica LEAF ON SERIAL SERUM BRAIN DERIVED NEUROTROPHIN FACTOR (BDNF) CONCENTRATION OF RATS (SPRAGUE DAWLEY) FOLLOWING CHRONIC STRESS
}

\author{
Dwi Cahyani Ratna Sari, Mawaddah Ar Rochmah \\ Department of Anatomy, Embryology, and Anthropology Gadjah Mada University. \\ Correspondence author: anat.fkugm@yahoo.com
}

\begin{abstract}
Centella asiatica is considered herbal plant for increasing memory performance. Brain-derived neurotrophin factor (BDNF) has a significant role in memory formation process, while stress causes memory impairment. Objective: This study aimed to investigate the effects of ethanol extracts of Centella asiatica leaf on serum BDNF concentration of rats that was taken serially before and after chronic electrical stress. Materials and Methods : Twenty male rats (Sprague Dawley) were divided into four groups: control/aquades group and groups treated with different doses (mg/kg) of Centella asiatica:150 (CA150), 300 (CA300) and 600 (CA600). Each rat underwent memory exercise for nine days before and after electrical stress and oral administration of ethanol extracts of Centella asiatica for twenty-eight days. Blood sampling was taken serially from rats' tail for four times : (1) before memory exercise, (2) after memory exercise (before stress), (3) after chronic stress, and (4) after memory exercise (following chronic stress). Concentration of serum BDNF was assessed using ELISA. Results: There was no significant difference in serum BDNF concentration between groups in first and second serum sampling, which was prior to chronic stress and administration of different treatments. However, there was significant difference in third and fourth serum sampling between groups. Mean concentration of serum BDNF $(\mathrm{ng} / \mathrm{ml})$ in third and fourth sampling for control group, CA150, CA300, and CA600, respectively were $1.88+0.21 \& 1.93+0.24 ; 2.29+0.13 \& 2.01+0.22 ; 2.29+0.08 \& 1.86+0.11 ; 2.71+0.70$ and 2.99+0.27 $(\mathrm{p}<0.05)$. Conclusion: Ethanol extracts of Centella asiatica leaf increases serum BDNF concentration in rats after chronic stress.
\end{abstract}

Key words: stress, memory, Centella asiatica, BDNF

\section{INTRODUCTION}

Centella asiatica is herbal plant, growing in moist places in Asian countries. Centella asiatica is widely used as herbal plants in traditional medicines in many countries in Asia. Some important chemical constituents found in Centella asiatica are triterpenoids and flavonoids (Zheng et al., 2007). Some studies highlighted asiatic acid and asiaticocide, which are parts of triterpenoids properties in Centella asiatica, that have functions in wound healing, brain stimulating effects, treatments of hypertension and microangiopathy, actions on gastric ulcer, and potent antioxidant and anticancer activity (Pittela et al., 2009, Krishnamurthi eet al., 2010). The effects of Centella asiatica to enhance memory performance in rats are affected by the duration of administration (Sari et al., 2011).

Stress may induce structural and functional alterations in the central nervous system and particularly in hippocampus (Venero et al., 2002). Hippocampal function is disturbed by the effect of chronic stress through such mechanisms as neuronal remodeling by dendritic retraction (Sousa et al., 2000), suppression of synaptic activity and plasticity (Morris et al., 2003), and altered neurogenesis (Leuner et al., 2006; Astari et al., 2012). In rats, chronic stress caused an impairment in the performance of spatial memory task in eight-arm radial maze (Leuner et al., 2006; Sari, 2011), Y-maze (Mclaughlin et al., 2009), and also water 
maze (Li et al., 2007, Sari et al., 2012). There are variety of experimental conditions in order to produce chronic stress, including 21 days of predator stress combined with high-fat diet (Baran et al., 2006), six days of activity stress combined with food restriction (Lambert et al., 1998), one month of chronic, unpredictable stress (Sousa et al., 2000), and daily tonefootshock for 21 consecutive days (Trentani et al., 2002).

Activity-dependent changes in synaptic strength are considered mechanisms underlying learning and memory. There are not only the structural changes of neurons in cerebral cortex and hippocampus that affect activity-dependent changes in synaptic strength, and alter learning and memory performance, but also molecular substances (Morris et al., 2003). Many studies suggest that Brain-derived neurotrophic factor (BDNF) has a significant role in the process of learning and memory, such as development of patterned connections, growth and complexity of dendrites in the cerebral cortex (Yamada et al., 2002). BDNF is a member of the neurotrophin family, including nerve growth factor (NGF), neurotrophin-3 (NT-3), and NT-4/5 (Leibrock et al., 1989). Recent experimental evidence supports the role of BDNF in memory processes: memory acquisition and consolidation are associated with an increase in BDNF mRNA expression and the activation of its receptor TrkB (Mizuno et al., 2003). $\mathrm{BDNF} / \mathrm{TrkB}$ signal transduction pathways may also participate in the process of learning and memory during chronic stress (Li et al., 2007). A study indicates that chronic mild repeated stress results in decrease of BDNF mRNA and protein (Shi et al., 2010).

Therefore, we have designed an investigation to study the neuroprotective effect of herbaceous cognitive enhancer, Centella asiatica, on serum BDNF concentration, that is believed to play an important role in learning and memory process, in chronic stressed-rats. Serum BDNF concentration is measured serially in order to assess the biochemical entities of learning and memory following chronic stress and different dose of Centella asiatica treatments.

\section{MATERIALS AND METHODS}

\section{A. Animals Experimental}

Twenty male Sprague Dawley rats (1 month old, 100 - 120 grams) were randomly divided into four groups: aquades (KN), CeA $150 \mathrm{mg} / \mathrm{kg}$ (KP1), CeA 300mg/kg (KP2), and $\mathrm{CeA} 600 \mathrm{mg} / \mathrm{kg}$ (KP3). Two animals were placed in the same house with food and water available ad libitum and maintained on a 12-h light:12-h dark cycle. The experiments were approved by Medical and Health Research Ethics Committee Faculty of Medicine Gadjah Mada University.

\section{B. Administration of Ethanol Extracts of Centella asiatica}

Ethanol extract of Centella asiatica was obtained using maceration methods from Integrated Testing and Research Institute of Gadjah Mada University. In order to prepare the various dose-dependent preparations : $150 \mathrm{mg} / \mathrm{kg}, 300 \mathrm{mg} / \mathrm{kg}$, and $600 \mathrm{mg} / \mathrm{kg}$, ethanol extracts of Centella asiatica was freshly diluted with sterile aquadest. Ethanol extracts of Centella asiatica were administrated orally for 28 consecutive days with weekly weight-adjusted dose. 


\section{Stress Procedure}

After oral administration of Centella asiatica, each rat was given electrical stress. The rodent electrical stressor (TW-0313) consisted of a box containing an animal space placed on a grid floor connected to a shock generator. Test rats received one session of electrical stress of total $10 \mathrm{~min} /$ day in the rodent electrical stresser in which inescapable footshocks were given [ $0.8 \mathrm{~mA}$ of electrical footshock in intensity and $10 \mathrm{~s}$ in duration with $15 \mathrm{~s}$ interval). Footshock stress was given chronically for 28 consecutive days.

\section{Blood Collection}

Blood was collected serially for four times. First blood sampling was collected at the beginning of study. Before receiving any treatment, each rat underwent memory exercise in Morris water maze everyday for nine consecutive days. Second blood sampling was collected an hour after final memory exercise in day nine. In the next day, each rat received oral administration of Centella asiatica and electrical stress according to its treatment group for twenty-eight consecutive days. Third blood sampling was collected an hour after final treatment in day twenty-eight. Memory exercise after chronic stress and treatment was performed for nine days. Fourth blood sampling was collected an hour after final memory exercise in day nine.

Blood was collected serially from rats' tail veins. Rat's tail was warmed with water for dilation of the vessels. An assistant held the tail to keep it steady and applied pressure at the base of the tail to further encourage dilation. A26 gauge needle was used to enter the vein. After blood collection, a sterile gauge was applied to the puncture site with pressure to stop the bleeding. From whole blood sample, serum was made by centrifugation $1500 \mathrm{rpm}, 4^{\circ} \mathrm{C}$, 10 minutes. Serum was kept in $-800 \mathrm{C}$ until measurement of BDNF concentration.

\section{E. Measurement of Serum BDNF Concentrations}

Serum concentration of BDNF was assessed using Rat BDNF ELISA Kit (Boster Immunoleader, Cat. EK0308).

\section{F. Statistic}

Results were expressed as mean \pm SE. Differences between groups were analyzed by ANOVA and t-Test using the SPSS software. Difference between groups were considered statistically significant at a $P$ value $<0.05$.

\section{RESULTS AND DISCUSSION}

Mean serum BDNF concentration in first, second, third, and fourth blood collection for all treatment groups are shown in Table 1. The data show that there was no significant difference in the first blood collection between groups. It means all rats had similar baseline in serum BDNF concentration prior to treatments. In the second blood collection, which was collected after the first memory exercise, there was no significant difference in serum BDNF concentration between groups. This result shows similar response to memory exercise in all groups before different treatments were given, in which mean serum BDNF level of all four groups was higher after the first memory exercise. 
There was significant difference between groups in serum BDNF concentration in third and fourth blood collection (Figure 1). In third blood collection, which was collected right after chronic electrical stress and different treatments to the groups, all treatment groups (KP1, $\mathrm{KP} 2$, and KP3) had significant higher serum BDNF level compared to control group (KN). While in fourth blood collection, which was collected after final memory exercise, only KP3 had significant higher serum BDNF level compared to the other groups.

Table 1. Mean Serum BDNF Concentration in Serial Blood Collection

\begin{tabular}{lcccc}
\hline & \multicolumn{4}{c}{ Mean Serum BDNF Concentration (ng/ml) } \\
\cline { 2 - 5 } & 1 & 2 & 3 & 4 \\
\hline $\mathrm{KN}$ (Aquades) & $1.928 \pm 0.258$ & $2.446 \pm 0.127$ & $1.88 \pm 0.21$ & $1.93 \pm 0.24$ \\
$\mathrm{KP} 1$ (CeA $150 \mathrm{mg} / \mathrm{kg})$ & $1.892 \pm 0.205$ & $2.056 \pm 0.311$ & $2.29 \pm 0.13^{*}$ & $2.01 \pm 0.22$ \\
$\mathrm{KP} 2(\mathrm{CeA} 300 \mathrm{mg} / \mathrm{kg})$ & $1.718 \pm 0.098$ & $2.156 \pm 0.238$ & $2.29 \pm 0.08^{*}$ & $1.86 \pm 0.11$ \\
$\mathrm{KP} 3(\mathrm{CeA} 600 \mathrm{mg} / \mathrm{kg})$ & $1.514 \pm 0.159$ & $2.102 \pm 0.25$ & $2.71 \pm 0.70^{* *}$ & $2.99 \pm 0.27 \#$ \\
\hline${ }^{*} \mathrm{P}<0.05$ vs KN group. ${ }^{* * \mathrm{P}}<0.01$ vs KN group. \# $\mathrm{P}<0.01 \mathrm{vs} \mathrm{KN}, \mathrm{KP} 2$, and KP3 groups.
\end{tabular}

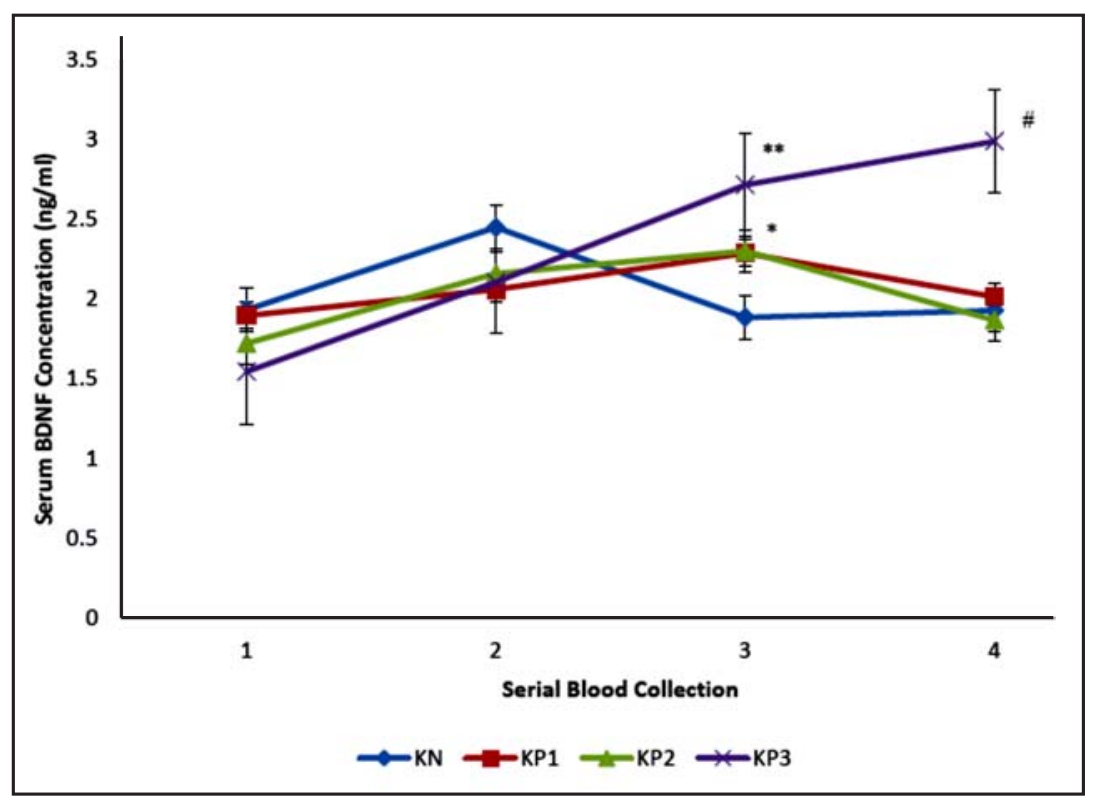

Figure 1. Serum BDNF level in serial blood collection. ${ }^{*} P<0.05$ vs $K N$ group. ${ }^{* *} P<0.01$ vs $K N$ group. \# $\mathrm{P}<0.01$ vs KN, KP2, and KP3 groups.

To our knowledge, this is the first study that reports serum BDNF level in serial blood collection following pre-stress memory exercise, oral treatment of Centella asiatica and chronic stress, and post-stress memory exercise. We used serum to measure BDNF concentration using ELISA method because according to previous studies serum BDNF is not affected by the handling of blood sample, its absorbancies are identical with those from whole blood to determine BDNF, and its storage is more stable that has been postulated for more than 12 months at $-20^{\circ} \mathrm{C}$ (Elfving et al., 2009). In this study, the samples were stored at $-80^{\circ} \mathrm{C}$ for less than 3 months, and therefore our samples are not likely to be affected from the storage conditions. Another study suggests that measurement of blood and plasma BDNF levels using ELISA method correlated with brain-tissue BDNF levels, including hippocampus and prefrontal cortex, across species (Klein et al., 2010). Therefore, we measured BDNF level in serum in order to discover its level in hippocampus. 
Memory exercise in this study was conducted using Morris water maze which requires the rats to swim in order to accomplish the task. This task in Morris water maze was not only for memory test purpose, but also for regular physical exercise (Terry, 2009). We found there were increasing serum BDNF level of all groups in second blood collection, which was collected after the first exercise in Morris water maze (Figure 1).

It is known that regular physical exercise also has beneficial effects for brain function, such as better memory performance (Radak, 2001), decreasing oxidative damage (Radak, 2001), enhancing capillarization for hippocampal neurogenesis (Fabel, 2001), and also increasing neurotrophin production (Radak, 2006). Unfortunately, the beneficial effects of training are proven reversibly in the brain, since detraining down regulates neurotrophin level and memory performance (Radak, 2006).

In this study, we proposed role of Centella asiatica in inducing BDNF concentration after chronic electrical stress. We found that Centella asiatica significantly increased serum BDNF concentration in all Centella asiatica treatment groups after chronic stress compared to control group. We also found that Centella asiatica significantly increased serum BDNF concentration after memory exercise following chronic stress only in KP3 group. Based on this study, we concluded that the effect of Centella asiatica is increasing BDNF level after stress but maintenance in increasing BDNF level is dose dependent.

BDNF and its receptor TrkB play important role during stress injury. Reduction of BDNF mRNA and protein expression were observed in the CA3 and the dentate gyrus of the hippocampus after repeated immobilization stress (Givalois et al., 2001), together with increased expression of TrkB mRNA (Nibuya et al., 1999), may play a role in neuronal plasticity process as an compensatory adaptation to the stress response. On the contrary, after a series of acute injuries, such as cerebral ischemia, epilepsy, or cerebral trauma, the up regulation of BDNF mRNA, as well as the augmentation of TrkB mRNA were observed in cerebral cortex and hippocampus (Rageet al., 2002).

Multiple chronic stresses change the protein expression and its gene regulation, as well as the post-synaptic density (PSD) composition in the hippocampus neuron (Sun et al., 2006, Liu et al., 2004). The main component of PSD is Fyn that is the molecular basis of learning and memory by its participation in synaptic plasticity (Kojima et al., 2007). BDNF/ TrkB signaling and NMDA receptors are very important for spatial memory formation. Fyn may play a key role in this interaction by linking TrkB with NR2 (Mizuno et al., 2003). Other study by same group also demonstrated contribution of BDNF inducing TrkB/Phosphatidil Inositol 3-Kinase (PI3-K) signaling pathway is critical for spatial learning in the radial arm maze (Mizuno et al., 2003). The TrkB signaling downstream effectors involved in BDNF/ TrkB signaling pathway, such as such as p-Akt, p-GSK-32, and p-mTOR in the hippocampus of rats, are also subjected to change following immobilization stress (Fang et al., 2013).

Centella asiatica was found to be able to increase serum BDNF level and maintain its increasing level at certain dose. An active component of Centella asiatica that has known as a cognitive enhancer is asiaticoside. Asiaticoside is also reported function as a dementiatreating agent (Kumar et al.,2011). In the previous studies using Centella asiatica as substance to ameliorate cognitive and memory function, the data was based on brain morphological improvement after treatment, such as enhancement of neuronal dendrites in growth 
spurt rats (Mohandas et al.,, 2006; Mohandas et al., 2009), the thickness of pyramidal layer in CA1 hippocampus (Sari eet al., 2012), and alteration of amyloid ${ }^{2}$ pathology in the brain of Alzheimer's disease animal models (Dhanasekaran et al., 2009). Centella asiatica was also proven to modulate components of the oxidative stress response in neurodegenerative mice (Kumar et al., 2011). In this study, we add the biochemical evidence of Centella asiatica that is able to increase serum BDNF level in chronic stressed-rats that may support the amelioration in memory function.

\section{CONCLUSION}

Centella asiatica ethanol extract treatment increases and maintains serum BDNF concentration after chronic stress.

\section{ACKNOWLEDGMENT}

The authors thank to Prof. Soedjono Aswin, MD, PhD, Rina Susilowati, MD, Ph.D, and Nur Arfian, MD, Ph.D for suggestion during completing this study.

\section{REFERENCES}

Astari, A.N., D.C.R. Sari, S. Aswin, and S. Suharmi. 2012. The Effect of Administration Pegagan Ethanolic Extract on the Number of Hippocampal CA3 Pyramidal Neuron: Study on Rats (Rattus norvegicus) post-stress Electricity with dose $300 \mathrm{mg} / \mathrm{kgBW}$ for 4 weeks and 6 weeks. Proceeding 23rd European Students Conference 17th-20th, Berlin, Germany.

Baran, S.E, A.M. Campbell, J.K. Kleen, C.H. Foltz, R.L. Wright, D.M. Diamond, and C.D. Conrad. 2006. Combination of High Fat Diet and Chronic Stress Retracts Hippocampal Dendrites. Neuroreport 16 (1): 39-43.

Dhanasekaran, M., L.A. Holcomb, A.R. Hitt, B. Tharakan, J.W. Porter, K.A. Young, and B.V. Manyam. 2009. "Centella asiatica Extract Selectively Decreases Amyloid ${ }^{2}$ Levels in Hippocampus of Alzheimer's Disease Animal Model. Phytotherapy Research, vol. 19, no. December $2008: 14-19$.

Elfving, B., P. H. Plougmann, and G. Wegener. 2010. Detection of Brain-derived Neurotrophic Factor (BDNF) in Rat Blood and Brain Preparations Using ELISA: Pitfalls and Solutions. Journal of Neuroscience Methods 187 (1) (March 15): 73-7.

Fabel, K., B. Tam, D. Kaufer, A. Baiker, N. Simmons, C.J. Kuo, and T.D. Palmer. 2003. VEGF is Necessary for Exercise-Induced Adult Hippocampal Neurogenesis. EurJ NeurosciNov 18(10):2803-12.

Fang, Z.H., C.H. Lee, M.K. Seo, H. Cho, J.G. Lee, B.J. Lee, S.W. Park, and Y.H. Kim. 2013. Effect of Treadmill Exercise on the BDNF-mediated Pathway in the Hippocampus of Stressed Rats. Neuroscience Research 76 (4) (August): 187-94.

Givalois, L., F. Marmigère, F. Rage, G. Ixart, S. Arancibia, and L. Tapia-Arancibia. 2001. Immobilization Stress Rapidly and Differentially Modulates BDNF and TrkB mRNA Expression in The Pituitary Gland of Adult Male Rats. Neuroendocrinology. Sep;74(3):148-59. 
Klein, A.B., R. Williamson, M.A. Santini, C. Clemmensen, A. Ettrup, M. Rios, G.M. Knudsen, and S. Aznar. 2011. Blood BDNF Concentrations Reflect Brain-tissue BDNF Levels Across Species. The International Journal of Neuropsychopharmacology / Official Scientific Journal of the Collegium Internationale Neuropsychopharmacologicum (CINP) 14 (3) (April): 347-53.

Kojima, N. 1997. Rescuing impairment of long-term potentiation in fyn-deficient mice by introducing Fyn transgene. Proc Natl Acad SciU S A 94(9): 4761-5.

Krishnamurthy, G. Rajanikant, M-C. Senut, D. Zemke, J. Min, B. Frenkel, E.J. Greenberg, SW. Yu. 2010. Asiatic Acid, a Pentacyclic Triterpene From Centella asiatica Is Neuroprotective in a Mouse Model of Focal Cerebral Ischemia. Journal of Neuroscience Research 87 (11): 2541-2550.

Kumar, A., A. Prakash, and S. Dogra. 2011. Centella asiatica Attenuates D-Galactose-Induced Cognitive Impairment, Oxidative and Mitochondrial Dysfunction in Mice. International journal of Alzheimer's disease, vol. 2011, p. 347569.

Lambert, K.G., S.K. Buckelew, G. S. Sandoz, S. Gaffga, W. Carpenter, J. Fisher, and C.H. Kinsley. 1998. Activity-stress Induces Atrophy of Apical Dendrites of Hippocampal Pyramidal Neurons in Male Rats. Physiology \& Behavior65 (1) (August): 43-9.

Leibrock, J., F. Lottspeich, A. Hohn, M. Hofer, B. Hengerer, P. Masia-kowski, H. Thoenen, and Y-A. Barde. 1989. Molecular cloning and expression of brain-derived neurotrophic factor. Nature, vol. 341:149-52.

Leuner, B., E. Gould, and T.J. Shors. 2006. Is There a Link Between Adult Neurogenesis and Learning? Hippocampus 16 (3) (January): 216-24.

Li, X-H., N-B. Liu, M-H. Zhang, Y-L. Zhou, J-W. Liao, X-Q. Liu, and H-W. Chen. 2007. Effects of chronic multiple stress on learning and memory and the expression of Fyn, BDNF, TrkB in the hippocampus of rats. Chinese Medical Journal, vol. 120 (8):669-674.

Liu, N.B. 2004. Chronic multiple stress enhances learning and memory capability in rats. Sheng Li Xue Bao 56(5): 615-9.

Mclaughlin, K.J., J. Gomez, S.E. Baran, and C. D. Conrad. 2009. Function : An Evaluation of Chronic Restraint Paradigms. Brain Research vol.1161:56-64.

Mizuno, M., K. Yamada, J. He, and A. Nakajima. 2003. Involvement of BDNF Receptor TrkB in Spatial Memory Formation. Learning \& Memory by Cold Spring Harbor Laboratory Press, vol. 10:108-115.

Mizuno, M., K. Yamada, N. Takei, M.H. Tran, J. He, A. Nakajima, H. Nawa, and T. Nabeshima. 2003. Phosphatidylinositol 3-kinase: a Molecule Mediating BDNF-dependent Spatial Memory Formation. Molecular Psychiatry 8 (2) (March): 217-24.

Mohandas, R.K.G., R.S. Muddanna, and R.S. Gurumadhva. 2006. Centella asiatica (L.) leaf extract treatment during the growth spurt period enhances hippocampal CA3 neuronal dendritic arborization in rats. Evidence-based complementary and alternative medicine: eCAM, vol. 3, no. 3, pp. 349-57, Sep. 2006.

Mohandas, R.K.G., R.S. Muddanna, and R.S. Gurumadhva. 2009. Enhancement of Amygdaloid Neuronal Dendritic Arborization by Fresh Leaf Juice of Centella asiatica (Linn) During Growth Spurt Period in Rats. Evidence-based complementary and alternative medicine : eCAM, vol. 6, no. 2, pp. 203-10, Jun. 
Morris, R.G.M., E.I. Moser, G. Riedel, S.J. Martin, J. Sandin, M. Day, and C. O'Carroll. 2003. Elements of a neurobiological theory of the hippocampus: the role of activity-dependent synaptic plasticity in memory. Philosophical transactions of the Royal Society of London. Series B, Biological sciences, vol. 358 (1432) : 773-86.

Nibuya, M., M. Takahashi, D.S. Russell, and R.S. Duman RS. 1999. Repeated Stress Increases Catalytic TrkB mRNA in Rat Hippocampus. Neurosci Lett. May 267(2):81-4.

Pittella, F., R.C. Dutra, D.D Junior, M.T.P. Lopes, and N.R. Barbosa. 2009. Antioxidant and Cytotoxic Activities of Centella asiatica (L) Urb. International Journal of Molecular Sciences 10 (9) (September): 3713-21.

Radak, Z., A. Toldy, Z. Szabo, S. Siamilis, C. Nyakas, G. Silye, J. Jakus, and S. Goto. 2006. The Effects of Training and Detraining on Memory, Neurotrophins and Oxidative Stress Markers in Rat Brain. Neurochemistry International 49 (4) (September): 387-92.

Radák, Z., T. Kaneko, S. Tahara, H. Nakamoto, J. Pucsok, M. Sasvári, C. Nyakas, and S. Goto. 2001. Regular exercise improves cognitive function and decreases oxidative damage in rat brain. Neurochem Int. Jan;38(1):17-23.

Rage, F., L. Givalois, F. Marmigère, L. Tapia-Arancibia, and S. Arancibia. 2002. Immobilization Stress Rapidly Modulates BDNF mRNA Expression in the Hypothalamus of Adult Male Rats. Neuroscience.112(2):309-18.

Sari, D.C.R. 2011. The Relationship between Memory, CA1 Hippocampus and Neuroglia after Centella asiatica Leaf Extract's Administration in Stress-Induced Rat (Rattus norvegicus). Proceeding of International Joint Symposium. Frontier in Biomedical Sciences: from Genes to Applications. Faculty of Medicine, UGM, Yogyakarta, Indonesia. Nov. 2011.

Sari, D.C.R., and M. Ar-Rochmah. 2012. The Effect of Ethanol Extracts of Centella Asiatica Leaf on the Retention of Spatial Memory in Rats (Sprague-dawley) after chronic electrical stress. Buku Panduan dan Kumpulan Abstract Pertemuan IImiah Nasional Perhimpunan Ahli Anatomi Indonesia XIV Komisariat PAAI Denpasar. Oct 2012.

Sari, D.C.R., R.S. Pratama, S. Aswin, and S. Suharmi. 2011. The effect of Centella asiatica ethanolic extract's administration duration on spatial memory in rat (Rattus norvegicus) after electric- stress induced. Jurnal kedokteran kesehatan mutiara medika UMY. Mutiara Medika Journal Kedokteran Kesehatan, vol. 11 (3).

Sari, D.C.R., S. Aswin, S. Suharmi, M. Romi, and U. Tranggono. 2012. The relationship between Spatial Memory and the Thickness of Hippocampal CA1 Pyramidal Layer in Stress-induced Rats (Rattus norvegicus) after Centella asiatica Leaf Extract's Administration. Nutrition \& Dietetics Journal of the Dietitians Association of Australia, including the Journal of Dietitians New Zealand. Vol 69. Supl. 1. Sept 2012.

Shi, S-S., S-H. Shao, B-P. Yuan, F. Pan, and Z-L. Li. 2010. Acute Stress and Chronic Stress Change Brain-derived Neurotrophic Factor (BDNF) and Tyrosine Kinase-coupled Receptor (TrkB) Expression in Both Young and Aged Rat Hippocampus. Yonsei Medical Journal51 (5) (September): 661-71.

Sousa, N., N. Lukoyanov, Md Madeira of Almeida, and M. Paula-Barbosa. 2000. Erratum to Reorganization of the Morphology of Hippocampal Neurites and Synapses After Stressinduced Damage Correlates with Behavioral Improvement. Neuroscience 101 (2) 
(January): 483.

Sun, C.Y. 2006. Changes of learning, memory and levels of CaMKII, CaM mRNA, CREB mRNA in the hippocampus of chronic multiple-stressed rats. Chin Med J (Engl), 119(2): 140-7.

Terry, A.V. 2009. Chapter 13 : Spatial Navigation (Water Maze) Tasks. Methods of Behavior Analysis in Neuroscience 2nd edition. Boca Raton (FL) CRC Press.

Trentani, A., S.D. Kuipers, G.J. Ter Horst, and J.A. Den Boer. 2002. Selective Chronic Stressinduced in Vivo ERK1/2 Hyperphosphorylation in Medial Prefrontocortical Dendrites: Implications for Stress-related Cortical Pathology?. European Journal of Neuroscience 15 (10) (May): 1681-1691.

Venero, C, T. Tilling, I. Hermans-Borgmeyer, R .Schmidt, M. Schachner, and C. Sandi. 2002. Chronic Stress Induces Opposite Changes in the mRNA Expression of the Cell Adhesion Molecules NCAM and L1. Neuroscience 115 (4) (January): 1211-9.

Yamada, K., M. Mizuno, and T. Nabeshima. 2002. Role for Brain-derived Neurotrophic Factor in Learning and Memory. Life Sciences 70 (7) (January 4): 735-44.

Zheng, C., and L. Qin. 2007. Chemicalcomponentsof Centellaasiatica andtheirbioactivities. Journal of Chinese Integrative Medicine, vol. 5:348-351. 